\title{
Rancang Bangun Sistem Informasi Geografis Pemetaan Daerah Rawan Kriminalitas di Kota Mataram Berbasis Web
}

\author{
Evandry Syahputra ${ }^{(1)}$, Ida Bagus Ketut Widiartha(2), Ariyan Zubaidi( ${ }^{(3)}$ \\ Program Studi Teknik Informatika Universitas Mataram \\ syahputraevandry8@gmail.com,widi@unram.ac.id, ariyan.zubaidi@unram.ac.id
}

\begin{abstract}
Mataram city has not applied the geographic information system about mapping of crime prone areas. It is make people hard to find the information about criminality. The purpose of this research is to build a system that can give information about location, mapping and help people to know the distribution point of criminality in Mataram city.This system is developed by Codeigniter Framework and using PHP and HTML programming language, it is also using Google Map API to display route of health facility. In this research using waterfall method as systems development life cycle. We use blackbox and MOS (Mean Opinion Score) as system testing. Result of blackbox testing the function in the system has been running nicely without having any errors, we got $44.21 \%, 50.34 \%$ and $4.01 \%$ as strongly agree, agree and neutral opinion using MOS. So in other hand, this system is feasible to use.
\end{abstract}

Keyword: geographic information system, health facility, web

\section{Abstrak}

Kota Mataram belum menerapkan sistem informasi geografis tentang pemetaan wilayah rawan kejahatan. Ini membuat orang sulit menemukan informasi tentang kriminalitas. Tujuan dari penelitian ini adalah untuk membangun sistem yang dapat memberikan informasi tentang lokasi, pemetaan dan membantu orang untuk mengetahui titik distribusi kriminalitas di kota Mataram. Sistem ini dikembangkan oleh Codeigniter Framework dan menggunakan bahasa pemrograman PHP dan HTML, juga menggunakan Google Map API untuk menampilkan rute fasilitas kesehatan. Dalam penelitian ini menggunakan metode waterfall sebagai siklus hidup pengembangan sistem. Kami menggunakan blackbox dan MOS (Mean Opinion Score) sebagai pengujian sistem. Hasil blackbox menguji fungsi dalam sistem telah berjalan dengan baik tanpa ada kesalahan, kami mendapat $44,21 \%, 50,34 \%$ dan $4,01 \%$ sangat setuju, setuju dan netral menggunakan MOS. Jadi di sisi lain, sistem ini layak digunakan.

Kata Kunci: geographic information system, health facility, web

\section{IPENDAHULUAN}

Kota Mataram merupakan Ibukota Nusa Tenggara Barat, sebagai salah satu kota terbesar di wilayah Indonesia timur dengan jumlah penduduk mencapai 450.226 jiwa. Salah satu masalah yang banyak terjadi di kota besar termasuk Kota Mataram adalah masalah kriminalitas, Berdasarkan data di Kota Mataram pada tahun 2016 telah terjadi tindak pidana sebanyak 1.140 kasus dengan kasus terbanyak merupakan tindak kriminalitas Pencurian 3C.

Dengan terus meningkatnya kriminalitas di Kota Mataram berdasarkan data kriminalitas kepolisian resort Kota Mataram dari tahun 2011 sampai 2016. Belum ada sistem yang mampu menganalisa dan memvisualisasikan hubungan antara tindak kriminalitas pencurian $3 \mathrm{C}$ dengan faktor-faktor seperti kepadatan penduduk, tingkat kemiskinan, tingkat pengangguran dan tingkat pendidikan. Sehingga pihak kepolisian resort Kota Mataram dan pemerintah Kota Mataram dapat mengambil suatu tindakan berdasar hasil analisa yang ada.

Pada dasarnya individu akan dipengaruhi oleh beberapa faktor seperti kemiskinan karena mengakibatkan banyak orang berputus asa sehingga kejahatan atau kriminalitas merupakan satu-satunya jalan menolong kehidupan, pengangguran memiliki pengaruh sosial karena pada dasarnya manusia tidak memiliki pekerjaan sekaligus tidak memiliki pendapatan, jumlah penduduk dapat berpengaruh pada tingkat kriminalitas di suatu daerah karena semakin banyak jumlah penduduk berpotensi semakin banyaknya pilihan korban, tingkat 
pendidikan dapat berpengaruh pada tingkat kriminalitas di suatu daerah karena merupakan faktor penting penentu tinggi rendahnya sumber daya manusia.

Oleh karena itu perlu dibuat suatu sistem informasi yang dapat membantu pihak kepolisian dan dinas terkait untuk menganalisa suatu daerah rawan kriminalitas dan memberi informasi kepada masyarakat tentang daerah rawan tindak kriminalitas berdasarkan tingkat kriminalitas per kecamatan di Kota Mataram serta informasi tentang hubungan antara kriminalitas dengan kepadatan penduduk, tingkat kemiskinan, tingkat pengangguran, tingkat pendidikan, sehingga informasi yang di dapat bisa digunakan pihak kepolisian dinas-dinas terkait untuk mengambil tindakan atau keputusan terkait tindak kriminalitas yang terjadi di Kota Mataram serta meningkatkan kewaspadaan masyarakat di Kota Mataram terhadap tindak kriminalitas pencurian 3C.

\section{TINJAUAN PUSTAKA}

Penelitian yang berjudul "SIGTIKEM merupakan aplikasi web-GIS yang menampilkan informasi tindak kejahatan multilevel yang terjadi di Kota Bogor yang dapat dimanfaatkan masyarakat sebagai acuan untuk melihat tindak kejahatan pada waktu tertentu dengan kriteria tertentu baik melalui intranet maupun internet. Informasi yang ditampilkan berupa data teks, peta, dan grafik. Tingkat kerawanan suatu daerah digambarkan dengan warna yang berbeda. Setiap jenis tindak kejahatan baik di level kota, kecamatan maupun level kelurahan yang sering terjadi akan lebih terlihat dengan berbeda warna pada peta sesuai dengan tingkat kerawanannya, sehinggaharapnya adalah adanya tindak lanjut dari pihak penegak hukum terhadap daerah yang sering terjadi tindak kejahatan. Selain data yang lebih rinci sebagai tambahan informasi ditampilkan pula data hasil perhitungan jumlah tindak kejahatan beserta penyelesaiannya. Adapun kekurangan dari sistem informasi ini adalah belum dapat menganalisa hubungan antara kriminalitas dengan data tingkat pengangguran dan tingkat pendidikan yang kemudian di tampilkan untuk dapat menganalisis kriminalitas per kecamatan di Kota Bogor [1].

Penelitian yang berjudul "'Sistem Informasi Geografis Daerah Rawan Kriminalitas di Kota Pontianak Berbasis Web" ini dikembangkan untuk membantu polisi untuk dapat memantau level kriminalitas berdasarkan data spasial ataupun data non-spasial, sehingga pihak kepolisian dapat mengontrol wilayahnya terhadap tindak kriminalitas serta menampilkan informasi kepada publik untuk dapat mengantisipasi tindak kriminalitas. Analisis dilakukan dengan metode Small Area Estimation (SAE) dan Empirical Bayes (EB) yang merupakan suatu teknik statistik untuk menduga parameterparameter sub populasi yang ukuran sampelnya kecil. Adapun kekurangan dari sistem ini adalah belum bisa secara dinamis menangani data kriminalitas tahunan dan hubungannya dengan faktor-faktornya [2].

Penelitian yang berjudul"Sistem InformasiGeografis Pemetaan Persebaran Kriminalitas di Kota Denpasar" sistem informasi ini dibangun untuk memberi informasi tentang persebaran kriminalitas yang terjadi di Kota Denpasar melalui pemetaan polygon. sistem ini diharapkan dapat membantu pihak terkait dalam melakukan analisis wilayah berdasarkan hasil pewarnaan polygon yang ditampilkan. Informasi yang diberikan dalam sistem ini berupa jumlah kriminalitas yang terjadi dan kategori wilayah tersebut, yaitu tingkat kriminalitas rendah, sedang, atau tinggi. ini dibantu juga oleh Metode Single Exponential Smoothing untuk meramalkan kejahatan yang terjadi pada bulan berikutnya, dimana hasil yang diberikan adalah mendekati hasil riil dengan data asli. Adapun kekurangan dari sistem ini adalah belum bisa secara dinamis menangani data kriminalitas tahunan dan hubungannya dengan faktor-faktornya [3].

\section{METODOLOGI PENELITIAN}

Proses pengembangan Sistem Informasi Geografis Pemetaan Daerah Rawan Kriminalitas di Kota Mataram Berbasis Web menggunakan metode pengembangan waterfall yang terdiri dari pendefinisian kebutuhan sistem, perancangan sistem, coding dan implementasi, pengujian, evaluasi sistem dan dokumentasi yang dapat dilihat pada Gambar 1 .

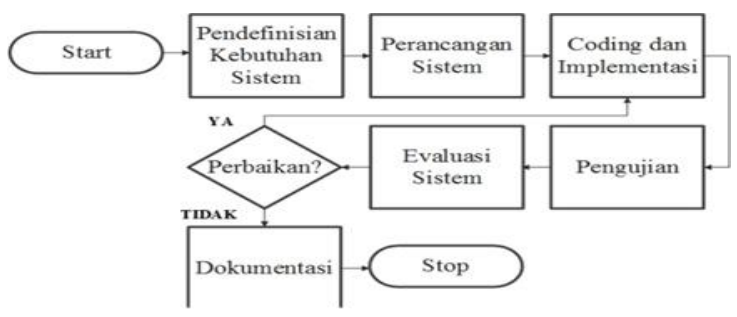

Gambar 1 Flowchart pengembangan sistem 


\section{A. Perancangan Database}

Tahap selanjutnya adalah perancangan database. Data-data yang ada di dalam sistem ini, seluruhnya akan disimpan di dalam satu database, sehingga data menjadi terintegrasi. Perancangan database perlu dilakukan agar penyimpanan data dapat dilakukan secara optimal dan mengurangi adanya duplikasi data yang juga dapat meminimumkan media penyimpanan. Perancangan database sistem informasi geografis pemetaan daerah rawan kriminalitas di Kota Mataram berbasis web dapat dilihat pada Gambar 2.

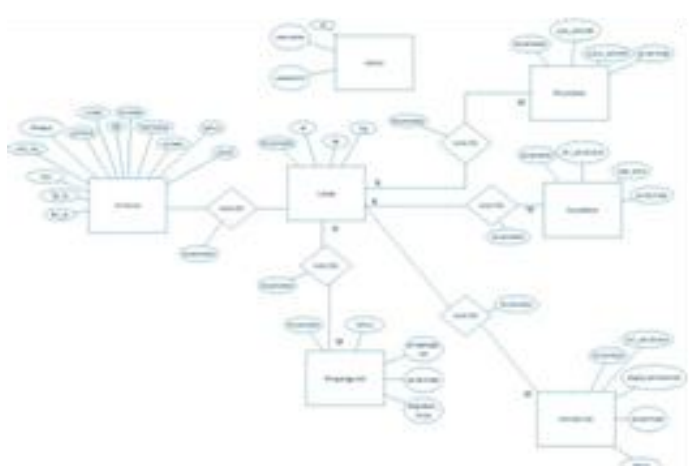

Gambar 2. ERD sistem informasi geografis daerah rawan kriminalitas.

\section{B. Perancangan Layout Sistem}

Tahapan selanjutnya adalah mendesain layout dari website yang akan dibangun. Layout ini nantinya akan menjadi interface yang akan berkomunikasi dengan user secara langsung seperti yang itunjukan pada Gambar 3, Gambar 4, Gambar 5 dan Gambar 6.

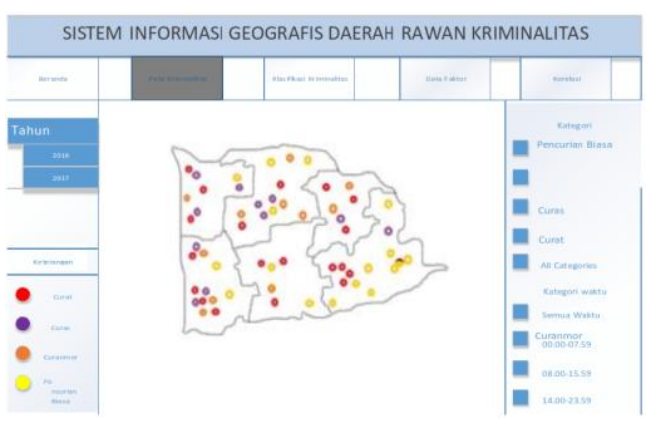

Gambar 3. Rancangan halaman peta kriminalitas

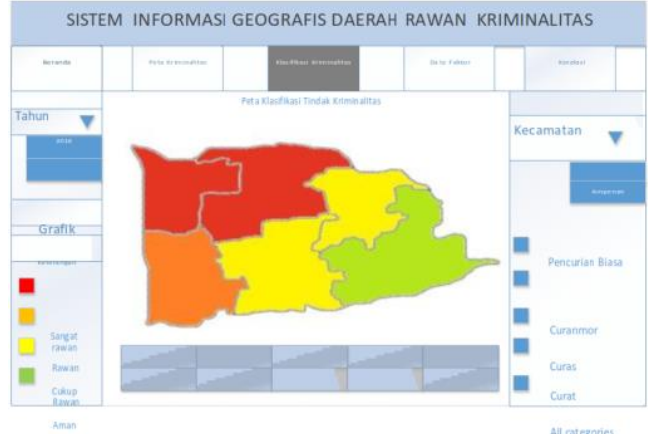

Gambar 4 Rancangan halaman melihat klasifikasi kriminalitas.

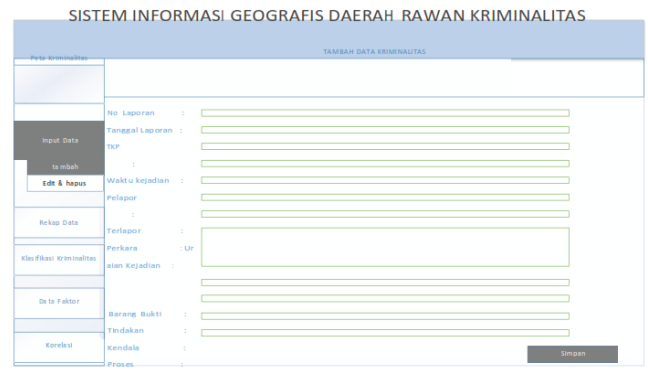

Gambar 5 Rancangan halaman input data.

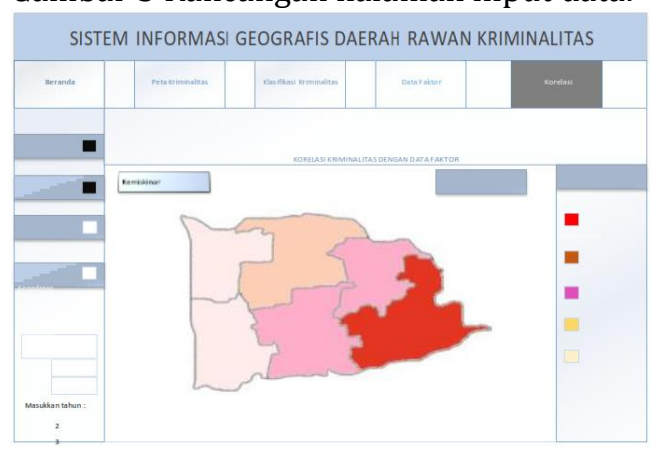

Gambar 6 Rancangan halaman korelasi.

\section{HASIL DAN IMPLEMENTASI \\ A. Implementasi Interface}

Implementasi yang dijabarkan adalah hasil implementasi sistem yang telah dirancang. Dimana hasil dari desain interface tersebut di ubah kedalam bahasa pemrograman, yaitu PHP dan HTML. Dibawah ini merupakan hasil dari implementasi interface yang telah di desain ditunjukan oleh Gambar 7, Gambar 8, Gambar 9 dan Gambar 10. 


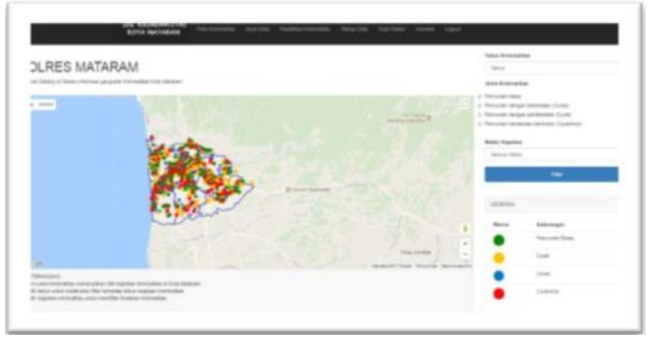

Gambar 7 Interface halaman fasilitas kesehatan.

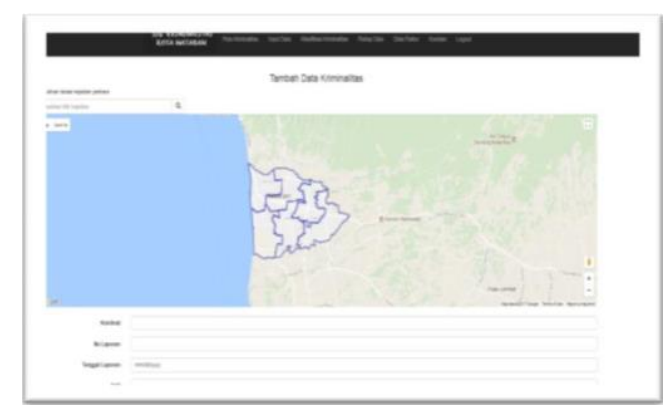

Gambar 8 Interface halaman input data

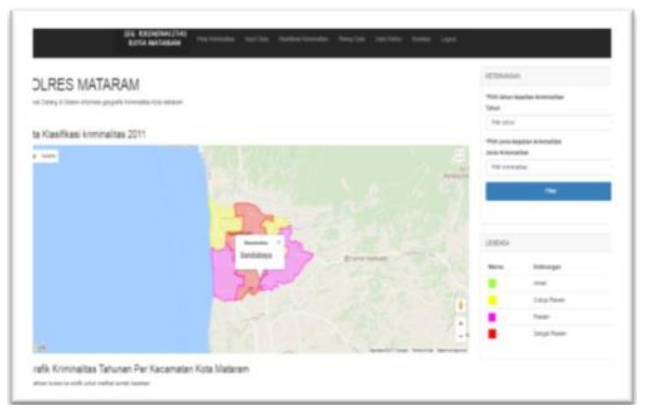

Gambar 9 Interface halaman klasifikasi kriminalitas

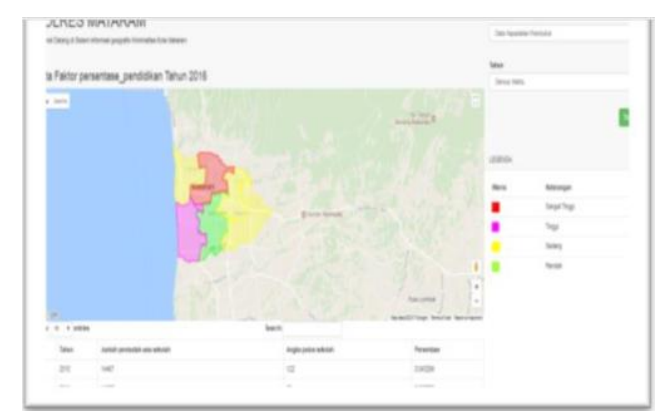

Gambar 10 Interface data faktor.

\section{B. Pengujian Sistem}

\section{Pengujian Black Box}

Metode pengujian black box merupakan metode pengujian yang menguji fungsi-fungsi di dalam sistem untuk menentukan apakah fungsifungsi tersebut sudah berjalan sesuai harapan atau tidak.

\section{Kuesioner}

Pengujian dengan menggunakan kuesioner dilakukan dengan mencari responden untuk mencoba menjalankan sistem, lalu memberikan pernyataan berupa kuesioner. Tujuan dari pengujian ini adalah mengetahui bagaimana kualitas sistem dilihat dari sisi pengguna. Pengujian ini dilakukan oleh 30 responden yang dipilih secara acak yang terdiri dari 20 pengguna umum dari sisi user, dan disisi admin 5 orang dari kalangan kepolisian dan 5 orang berasal dari Badan Pusat Statistik Kota Mataram.

Hasil dari jawaban responden nantinya akan dihitung dan ditarik kesimpulan mengenai hasil pengujian sistem. Kuesioner pengujian sistem yang diberikan untuk masyarakat umum dan mahasiswa terdiri dari tujuh pernyataan, yaitu:

1. Apakah komposisi warna website menarikuntuk dilihat?

2. Tampilan sistem mudah digunakan?

3. Navigasi yang digunakan mudah untuk dipahami?

4. Sistem dapat memberikan informasi mengenai titik persebaran kriminalitas 3C (Pencurian, Curas, Curat dan Curanmor) di Kota Mataram?

5. Sistem dapat memberikan informasi mengenai daerah rawan kriminalitas berdasarkan kecamatan di Kota Mataram?

6. Sistem dapat memberikan informasi mengenai hubungan tingkat kriminalitas dan data faktor kriminalitas?

7. Sistem dapat digunakan sebagai media yang membantu masyarakat dalam meningkatkan kewaspadaan terhadap tindak kriminalitas di Kota Mataram?

Kuesioner diberikan untuk Kepolisian resort Kota Mataram terdiri dari tujuh pertanyaan, yaitu:

1. Apakah komposisi warna website menarikuntuk dilihat?

2. Tampilan sistem mudah digunakan?

3. Navigasi yang digunakan mudah untuk dipahami?

4. Sistem dapat memberikan informasi mengenai titik persebaran kriminalitas 3C (Pencurian, Curas, Curat dan Curanmor) di Kota Mataram?

5. Sistem dapat memberikan informasi mengenai daerah rawan kriminalitas berdasarkan kecamatan di Kota Mataram? 
6. Sistem dapat memberikan informasi mengenai hubungan tingkat kriminalitas dan data faktor kriminalitas?

7. Sistem dapat digunakan sebagai media yang membantu masyarakat dalam meningkatkan kewaspadaan terhadap tindak kriminalitas di Kota Mataram?

Kuesioner Badan Pusat Statistik Kota Mataram terdiri dari tujuh pertanyaan, yaitu:

1. Apakah komposisi warna website menarik untuk dilihat?

2. Tampilan sistem mudah digunakan?

3. Navigasi yang digunakan mudah untuk dipahami?

4. Sistem dapat memberikan informasi mengenai titik persebaran kriminalitas 3C (Pencurian, Curas, Curat dan Curanmor) di Kota Mataram?

5. Sistem dapat membantu proses input data kepadatan, kemiskinan, pendidikan dan data faktor

6. Sistem dapat memberikan informasi mengenai hubungan tingkat kriminalitas dan data faktor kriminalitas?

7. Sistem dapat digunakan sebagai media yang membantu dalam klasifikasi data tingkat kepadatan, kemiskinan, pendidikan dan pengangguran di Kota Mataram?

Lalu dari pernyataan tersebut, responden diminta untuk menjawab dengan nilai-nilai tertentu, diantaranya:

$$
\begin{array}{ll}
\text { 1. } & 1 \text { = Sangat tidak setuju } . \\
\text { 2. } & 2 \text { = Tidak setuju. } \\
\text { 3. } & 3 \text { = Cukup. } \\
\text { 4. } & 4=\text { Setuju. } \\
\text { 5. } & 5=\text { Sangat setuju }
\end{array}
$$

Berdasarkan jawaban tersebut, langkah selanjutnya adalah menghitung persentase dari setiap jawaban yang diberikan oleh pengguna di setiap pernyataan. Rumus untuk menghitung persentase nilai adalah sebagai berikut:

\section{Persentase $=\mathrm{J} / \mathrm{N} * 100 \%$}

Keterangan:

J : total nilai jawaban yang diberikan pengguna pada setiap nomor.

$\mathrm{N}$ : jumlah pengguna.
Dengan menggunakan rumus perhitungan diatas, perhitungan untuk hasil jawaban pengguna pada setiap pertanyaan pada kuesioner dapat dilihat pada Tabel 1, Tabel 2, Tabel 3, Tabel 4, Tabel 5, Tabel 6 dan Tabel 7 . Dan grafik persentase jawaban responden masyarakat umum dapat dilihat pada Gambar 10.

Tabel 1 Hasil kuesioner user pernyataan nomor 1.

\begin{tabular}{|c|c|c|c|}
\hline $\begin{array}{c}\text { Katagori } \\
\text { Jawaban }\end{array}$ & $\begin{array}{c}\text { Jumlah } \\
\text { Jawaban }\end{array}$ & $\begin{array}{c}\text { Jumlah } \\
\text { Responden }\end{array}$ & Persentase \\
\hline $\begin{array}{c}\text { Sangat } \\
\text { setuju }\end{array}$ & 6 & 20 & $30 \%$ \\
\hline Setuju & 14 & 20 & $70 \%$ \\
\hline Cukup & 0 & 20 & $0 \%$ \\
\hline $\begin{array}{c}\text { Tidak } \\
\text { setuju }\end{array}$ & 0 & 20 & $0 \%$ \\
\hline $\begin{array}{c}\text { Sangat } \\
\text { tidak Setuju }\end{array}$ & 0 & 20 & $0 \%$ \\
\hline
\end{tabular}

Tabel 2. Hasil kuesioner user pernyataan nomor 2.

\begin{tabular}{|c|c|c|c|}
\hline $\begin{array}{c}\text { Katagori } \\
\text { Jawaban }\end{array}$ & $\begin{array}{c}\text { Jumlah } \\
\text { Jawaban }\end{array}$ & $\begin{array}{c}\text { Jumlah } \\
\text { Responden }\end{array}$ & Persentase \\
\hline Sangat setuju & 7 & 20 & $35 \%$ \\
\hline Setuju & 11 & 20 & $55 \%$ \\
\hline Cukup & 2 & 20 & $10 \%$ \\
\hline Tidak setuju & 0 & 20 & $0 \%$ \\
\hline $\begin{array}{c}\text { Sangat tidak } \\
\text { Setuiu }\end{array}$ & 0 & 20 & $0 \%$ \\
\hline
\end{tabular}

Tabel 3 Hasil kuesioner user pernyataan nomor 3 .

\begin{tabular}{|c|c|c|c|}
\hline $\begin{array}{c}\text { Katagori } \\
\text { Jawaban }\end{array}$ & $\begin{array}{c}\text { Jumlah } \\
\text { Jawaban }\end{array}$ & $\begin{array}{c}\text { Jumlah } \\
\text { Responden }\end{array}$ & Persentase \\
\hline Sangat setuju & 11 & 20 & $55 \%$ \\
\hline Setuju & 8 & 20 & $40 \%$ \\
\hline Cukup & 1 & 20 & $5 \%$ \\
\hline Tidak setuju & 0 & 20 & $0 \%$ \\
\hline $\begin{array}{c}\text { Sangat tidak } \\
\text { Setuju }\end{array}$ & 0 & 20 & $0 \%$ \\
\hline
\end{tabular}

Tabel 4 Hasil kuesioner user pernyataan nomor 4.

\begin{tabular}{|c|c|c|c|}
\hline $\begin{array}{c}\text { Katagori } \\
\text { Jawaban }\end{array}$ & $\begin{array}{c}\text { Jumlah } \\
\text { Jawaban }\end{array}$ & $\begin{array}{c}\text { Jumlah } \\
\text { Responden }\end{array}$ & Persentase \\
\hline Sangat setuju & 6 & 20 & $30 \%$ \\
\hline Setuju & 14 & 20 & $70 \%$ \\
\hline Cukup & 0 & 20 & $0 \%$ \\
\hline Tidak setuju & 0 & 20 & $0 \%$ \\
\hline $\begin{array}{c}\text { Sangat tidak } \\
\text { Setuju }\end{array}$ & 0 & 20 & $0 \%$ \\
\hline
\end{tabular}

Tabel 5 Hasil kuesioner user pernyataan nomor 5.

\begin{tabular}{|c|c|c|c|}
\hline $\begin{array}{c}\text { Katagori } \\
\text { Jawaban }\end{array}$ & $\begin{array}{c}\text { Jumlah } \\
\text { Jawaban }\end{array}$ & $\begin{array}{c}\text { Jumlah } \\
\text { Responden }\end{array}$ & Persentase \\
\hline Sangat setuju & 4 & 20 & $20 \%$ \\
\hline Setuju & 10 & 20 & $50 \%$ \\
\hline Cukup & 6 & 20 & $30 \%$ \\
\hline Tidak setuju & 0 & 20 & $0 \%$ \\
\hline $\begin{array}{c}\text { Sangat tidak } \\
\text { Setuju }\end{array}$ & 0 & 20 & $0 \%$ \\
\hline
\end{tabular}



http://e-journal.stmiklombok.ac.id/index.php/misi

Tabel 6 Hasil kuesioner user pernyataan nomor 6 .

\begin{tabular}{|c|c|c|c|}
\hline $\begin{array}{c}\text { Katagori } \\
\text { Jawaban }\end{array}$ & $\begin{array}{c}\text { Jumlah } \\
\text { Jawaban }\end{array}$ & $\begin{array}{c}\text { Jumlah } \\
\text { Responden }\end{array}$ & Persentase \\
\hline Sangat setuju & 4 & 20 & $20 \%$ \\
\hline Setuju & 13 & 20 & $65 \%$ \\
\hline Cukup & 2 & 20 & $10 \%$ \\
\hline Tidak setuju & 1 & 20 & $5 \%$ \\
\hline $\begin{array}{c}\text { Sangat tidak } \\
\text { Setuju }\end{array}$ & 0 & 20 & 0 \\
\hline
\end{tabular}

Tabel 7 Hasil kuesioner user pernyataan nomor 7.

\begin{tabular}{|c|c|c|c|}
\hline $\begin{array}{c}\text { Katagori } \\
\text { Jawaban }\end{array}$ & $\begin{array}{c}\text { Jumlah } \\
\text { Jawaban }\end{array}$ & $\begin{array}{c}\text { Jumlah } \\
\text { Responden }\end{array}$ & Persentase \\
\hline Sangat setuju & 3 & 20 & $15 \%$ \\
\hline Setuju & 12 & 20 & $60 \%$ \\
\hline Cukup & 5 & 20 & $25 \%$ \\
\hline Tidak setuju & 0 & 20 & $0 \%$ \\
\hline $\begin{array}{c}\text { Sangat tidak } \\
\text { Setuju }\end{array}$ & 0 & 20 & $0 \%$ \\
\hline
\end{tabular}

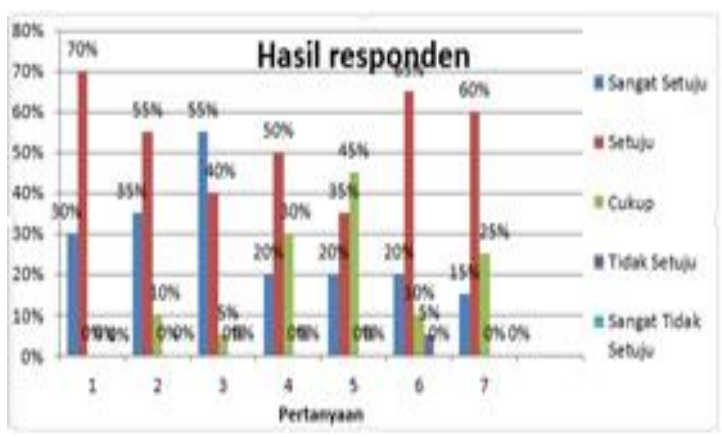

Gambar 10 Grafik persentase jawaban responden masyarakat umum.

Perhitungan untuk hasil jawaban pengguna disisi admin pada setiap pertanyaan pada kuesioner dapat dilihat pada Tabel 8, Tabel 9, Tabel 10, Tabel11 dan Tabel 12 Tabel 13 dan Tabel 14. Dan grafik persentase jawaban responden Kepolisian dapat dilihat pada Gambar 11.

Tabel 8 Hasil kuesioner admin pernyataan nomor 1.

\begin{tabular}{|c|c|c|c|}
\hline $\begin{array}{c}\text { Katagori } \\
\text { Jawaban }\end{array}$ & $\begin{array}{c}\text { Jumlah } \\
\text { Jawaban }\end{array}$ & $\begin{array}{c}\text { Jumlah } \\
\text { Responden }\end{array}$ & Persentase \\
\hline Sangat setuju & 0 & 5 & $0 \%$ \\
\hline Setuju & 5 & 5 & $100 \%$ \\
\hline Cukup & 0 & 5 & $0 \%$ \\
\hline Tidak setuju & 0 & 5 & $0 \%$ \\
\hline $\begin{array}{c}\text { Sangat tidak } \\
\text { Setuju }\end{array}$ & 0 & 5 & $0 \%$ \\
\hline
\end{tabular}

Tabel 9. Hasil kuesioner admin pernyataan nomor 2.

\begin{tabular}{|c|c|c|c|}
\hline $\begin{array}{c}\text { Katagori } \\
\text { Jawaban }\end{array}$ & $\begin{array}{c}\text { Jumlah } \\
\text { Jawaban }\end{array}$ & $\begin{array}{c}\text { Jumlah } \\
\text { Responden }\end{array}$ & Persentase \\
\hline $\begin{array}{c}\text { Sangat } \\
\text { setuju }\end{array}$ & 4 & 5 & $80 \%$ \\
\hline Setuju & 1 & 5 & $20 \%$ \\
\hline Cukup & 0 & 5 & $0 \%$ \\
\hline Tidak setuju & 0 & 5 & $0 \%$ \\
\hline $\begin{array}{c}\text { Sangat tidak } \\
\text { Setuju }\end{array}$ & 0 & 5 & $0 \%$ \\
\hline
\end{tabular}

Tabel 10 Hasil kuesioner admin pernyataan nomor 3.

\begin{tabular}{|c|c|c|c|}
\hline $\begin{array}{c}\text { Katagori } \\
\text { Jawaban }\end{array}$ & $\begin{array}{c}\text { Jumlah } \\
\text { Jawaban }\end{array}$ & $\begin{array}{c}\text { Jumlah } \\
\text { Responden }\end{array}$ & Persentase \\
\hline $\begin{array}{c}\text { Sangat } \\
\text { setuju }\end{array}$ & 0 & 5 & $0 \%$ \\
\hline Setuju & 3 & 5 & $60 \%$ \\
\hline Cukup & 2 & 5 & $40 \%$ \\
\hline $\begin{array}{c}\text { Tidak } \\
\text { setuju }\end{array}$ & 0 & 5 & $0 \%$ \\
\hline $\begin{array}{c}\text { Sangat } \\
\text { tidak Setuju }\end{array}$ & 0 & 5 & $0 \%$ \\
\hline
\end{tabular}

Tabel 11 Hasil kuesioner admin pernyataan nomor 4.

\begin{tabular}{|c|c|c|c|}
\hline $\begin{array}{c}\text { Katagori } \\
\text { Jawaban }\end{array}$ & $\begin{array}{c}\text { Jumlah } \\
\text { Jawaban }\end{array}$ & $\begin{array}{c}\text { Jumlah } \\
\text { Responden }\end{array}$ & Persentase \\
\hline $\begin{array}{c}\text { Sangat } \\
\text { setuju }\end{array}$ & 3 & 5 & $60 \%$ \\
\hline Setuju & 1 & 5 & $20 \%$ \\
\hline Cukup & 1 & 5 & $20 \%$ \\
\hline Tidak setuju & 0 & 5 & $0 \%$ \\
\hline $\begin{array}{c}\text { Sangat tidak } \\
\text { Setuju }\end{array}$ & 0 & 5 & $0 \%$ \\
\hline
\end{tabular}

Tabel 12 Hasil kuesioner admin pernyataan nomor 5.

\begin{tabular}{|c|c|c|c|}
\hline $\begin{array}{c}\text { Katagori } \\
\text { Jawaban }\end{array}$ & $\begin{array}{c}\text { Jumlah } \\
\text { Jawaban }\end{array}$ & $\begin{array}{c}\text { Jumlah } \\
\text { Responden }\end{array}$ & Persentase \\
\hline Sangat & 2 & 5 & $40 \%$ \\
\hline Setuju & 2 & 5 & $40 \%$ \\
\hline Cukup & 1 & 5 & $20 \%$ \\
\hline Tidak & 0 & 5 & $0 \%$ \\
\hline $\begin{array}{c}\text { Sangat } \\
\text { tidak Setuju }\end{array}$ & 0 & 5 & $0 \%$ \\
\hline
\end{tabular}

Tabel 13 Hasil kuesioner admin pernyataan nomor 6

\begin{tabular}{|c|c|c|c|}
\hline $\begin{array}{c}\text { Katagori } \\
\text { Jawaban }\end{array}$ & $\begin{array}{c}\text { Jumlah } \\
\text { Jawaban }\end{array}$ & $\begin{array}{c}\text { Jumlah } \\
\text { Responden }\end{array}$ & Persentase \\
\hline $\begin{array}{c}\text { Sangat } \\
\text { setuju }\end{array}$ & 0 & 5 & $0 \%$ \\
\hline Setuju & 3 & 5 & $60 \%$ \\
\hline Cukup & 1 & 5 & $20 \%$ \\
\hline Tidak setuju & 1 & 5 & $20 \%$ \\
\hline $\begin{array}{c}\text { Sangat tidak } \\
\text { Setuju }\end{array}$ & 0 & 5 & $0 \%$ \\
\hline
\end{tabular}

Tabel 14 Hasil kuesioner admin pernyataan nomor 7.

\begin{tabular}{|c|c|c|c|}
\hline $\begin{array}{c}\text { Katagori } \\
\text { Jawaban }\end{array}$ & $\begin{array}{c}\text { Jumlah } \\
\text { Jawaban }\end{array}$ & $\begin{array}{c}\text { Jumlah } \\
\text { Responden }\end{array}$ & Persentase \\
\hline $\begin{array}{c}\text { Sangat } \\
\text { setuju }\end{array}$ & 2 & 5 & $40 \%$ \\
\hline Setuju & 1 & 5 & $20 \%$ \\
\hline Cukup & 2 & 5 & $40 \%$ \\
\hline Tidak setuju & 0 & 5 & $0 \%$ \\
\hline $\begin{array}{c}\text { Sangat tidak } \\
\text { Setuju }\end{array}$ & 0 & 5 & $0 \%$ \\
\hline
\end{tabular}




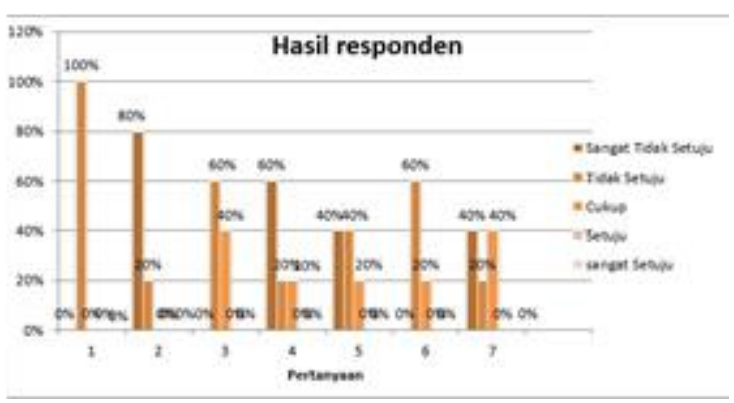

Gambar 11 Grafik persentase jawaban responden Kepolisian.

Perhitungan untuk hasil jawaban pengguna disisi admin pada setiap pertanyaan pada kuesioner dapat dilihat pada Tabel 15, Tabel 16, Tabel 17, Tabel 18 dan Tabel 19 Tabel 20 dan Tabel 21. Dan grafik persentase jawaban responden Kepolisian dapat dilihat pada Gambar 12.

Tabel 15 Hasil kuesioner admin pernyataan nomor 1 .

\begin{tabular}{|c|c|c|c|}
\hline $\begin{array}{c}\text { Katagori } \\
\text { Jawaban }\end{array}$ & $\begin{array}{c}\text { Jumlah } \\
\text { Jawaban }\end{array}$ & $\begin{array}{c}\text { Jumlah } \\
\text { Responden }\end{array}$ & Persentase \\
\hline Sangat setuju & 2 & 5 & $40 \%$ \\
\hline Setuju & 2 & 5 & $40 \%$ \\
\hline Cukup & 1 & 5 & $20 \%$ \\
\hline Tidak setuju & 0 & 5 & $0 \%$ \\
\hline $\begin{array}{c}\text { Sangat tidak } \\
\text { Setuju }\end{array}$ & 0 & 5 & $0 \%$ \\
\hline
\end{tabular}

Tabel 16 Hasil kuesioner admin pernyataan nomor 2 .

\begin{tabular}{|c|c|c|c|}
\hline $\begin{array}{c}\text { Katagori } \\
\text { Jawaban }\end{array}$ & $\begin{array}{c}\text { Jumlah } \\
\text { Jawaban }\end{array}$ & $\begin{array}{c}\text { Jumlah } \\
\text { Responden }\end{array}$ & Persentase \\
\hline Sangat setuju & 1 & 5 & $20 \%$ \\
\hline Setuju & 3 & 5 & $60 \%$ \\
\hline Cukup & 1 & 5 & $20 \%$ \\
\hline Tidak setuju & 0 & 5 & $0 \%$ \\
\hline $\begin{array}{c}\text { Sangat tidak } \\
\text { Setuju }\end{array}$ & 0 & 5 & $0 \%$ \\
\hline
\end{tabular}

Tabel 17 Hasil kuesioner admin pernyataan nomor 3 .

\begin{tabular}{|c|c|c|c|}
\hline $\begin{array}{c}\text { Katagori } \\
\text { Jawaban }\end{array}$ & $\begin{array}{c}\text { Jumlah } \\
\text { Jawaban }\end{array}$ & $\begin{array}{c}\text { Jumlah } \\
\text { Responden }\end{array}$ & Persentase \\
\hline Sangat setuju & 0 & 5 & $0 \%$ \\
\hline Setuju & 2 & 5 & $40 \%$ \\
\hline Cukup & 3 & 5 & $60 \%$ \\
\hline Tidak setuju & 0 & 5 & $0 \%$ \\
\hline $\begin{array}{c}\text { Sangat tidak } \\
\text { Setuju }\end{array}$ & 0 & 5 & $0 \%$ \\
\hline
\end{tabular}

Tabel 18 Hasil kuesioner admin pernyataan nomor 4.

\begin{tabular}{|c|c|c|c|}
\hline $\begin{array}{c}\text { Katagori } \\
\text { Jawaban }\end{array}$ & $\begin{array}{c}\text { Jumlah } \\
\text { Jawaban }\end{array}$ & $\begin{array}{c}\text { Jumlah } \\
\text { Responden }\end{array}$ & Persentase \\
\hline Sangat setuju & 0 & 5 & $0 \%$ \\
\hline Setuju & 4 & 5 & $80 \%$ \\
\hline Cukup & 1 & 5 & $20 \%$ \\
\hline Tidak setuju & 0 & 5 & $0 \%$ \\
\hline $\begin{array}{c}\text { Sangat tidak } \\
\text { Setuju }\end{array}$ & 0 & 5 & $0 \%$ \\
\hline
\end{tabular}

Tabel 19 Hasil kuesioner admin pernyataan nomor 5.

\begin{tabular}{|c|c|c|c|}
\hline $\begin{array}{c}\text { Katagori } \\
\text { Jawaban }\end{array}$ & $\begin{array}{c}\text { Jumlah } \\
\text { Jawaban }\end{array}$ & $\begin{array}{c}\text { Jumlah } \\
\text { Responden }\end{array}$ & Persentase \\
\hline Sangat setuju & 3 & 5 & $60 \%$ \\
\hline Setuju & 1 & 5 & $20 \%$ \\
\hline Cukup & 1 & 5 & $20 \%$ \\
\hline Tidak setuju & 0 & 5 & $0 \%$ \\
\hline $\begin{array}{c}\text { Sangat tidak } \\
\text { Setuju }\end{array}$ & 0 & 5 & $0 \%$ \\
\hline
\end{tabular}

Tabel 20 Hasil kuesioner admin pernyataan nomor 6.

\begin{tabular}{|c|c|c|c|}
\hline $\begin{array}{c}\text { Katagori } \\
\text { Jawaban }\end{array}$ & $\begin{array}{c}\text { Jumlah } \\
\text { Jawaban }\end{array}$ & $\begin{array}{c}\text { Jumlah } \\
\text { Responden }\end{array}$ & Persentase \\
\hline Sangat setuju & 0 & 5 & $0 \%$ \\
\hline Setuju & 2 & 5 & $40 \%$ \\
\hline Cukup & 2 & 5 & $40 \%$ \\
\hline Tidak setuju & 1 & 5 & $20 \%$ \\
\hline $\begin{array}{c}\text { Sangat tidak } \\
\text { Setuju }\end{array}$ & 0 & 5 & $0 \%$ \\
\hline
\end{tabular}

Tabel 21 Hasil kuesioner admin pernyataan nomor 7.

\begin{tabular}{|c|c|c|c|}
\hline $\begin{array}{c}\text { Katagori } \\
\text { Jawaban }\end{array}$ & $\begin{array}{c}\text { Jumlah } \\
\text { Jawaban }\end{array}$ & $\begin{array}{c}\text { Jumlah } \\
\text { Responden }\end{array}$ & Persentase \\
\hline Sangat setuju & 1 & 5 & $20 \%$ \\
\hline Setuju & 2 & 5 & $40 \%$ \\
\hline Cukup & 2 & 5 & $40 \%$ \\
\hline Tidak setuju & 0 & 5 & $0 \%$ \\
\hline $\begin{array}{c}\text { Sangat tidak } \\
\text { Setuiu }\end{array}$ & 0 & 5 & $0 \%$ \\
\hline
\end{tabular}

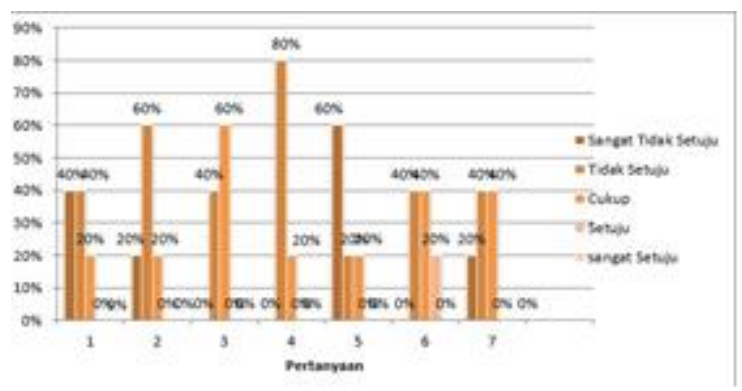

Gambar 15 Grafik persentase jawaban responden Badan Pusat Statistik. 


\section{KESIMPULAN DAN SARAN}

A. Kesimpulan

1. Sistem admin kepolisian dalam memasukkan data lokasi kejadian kriminalitas sehingga sistem mampu menggambarkan wilayah rawan kriminalitas serta memudahkan pihak kepolisian untuk melakukan monitoring terhadap tindak kriminalitas di Kota Mataram.

2. Sistem yang dibuat dilengkapi dengan rekap data kriminalitas dan data faktor yang berupa data kepadatan, kemiskinan, pendidikan dan pengangguran untuk memudahkan pihak badan pusat statistik dalam mengelola data tahunan.

3. Sistem mampu memberikan informasi hubungan antara tindak kriminalitas dengan data faktor dari badan pusat statistik.

4. Sistem mampu memberikan gambaran peta persebaran titik kriminalitas berdasarkan data yang diinputkan oleh pihak kepolisian.

5. Dari hasil pengujian black box menunjukkan bahwa seluruh fungsi pada halaman admin dan user telah berjalan sesuai dengan sistem yang diusulkan.

6. Berdasarkan kuisioner yang telah dibagikan kepada masyarakat dan mahasiswa, sistem ini dapat membantu masyarakat dalam memberikan informasi terkait tindak kriminalitas di Kota Mataram dengan angka hasil kuesioner sangat setuju sebanyak 24\% setuju $48 \%$ dan cukup $28 \%$.

7. Berdasarkan kuesioner yang telah dibagikan, sistem ini memudahkan admin badan pusat statistik untuk mengelola data faktor tahunan dengan hasil kuesioner sangat setuju dan setuju masing-masing sebanyak 20\% dan $46 \%$.

8. Sistem telah mampu memberikan informasi hubungan antara tindak kriminalitas denganmdata faktor serta membantu kepolisian dalam menganalisa tindak kriminalitas dengan hasil kuesioner sangat setuju sebanyak $31 \%$, setuju $46 \%$ dan cukup $20 \%$

B. Saran

1. Untuk penelitian selanjutnya, peneliti bias mengembangkan dalam mobile agar lebih efisien dalam penggunaanya.

2. Untuk penelitian selanjutnya peneliti bisa menambahkan data per kelurahan sehingga data menjadi lebih akurat untuk melihat tingkat kriminalitas di Kota Mataram.
3. Untuk penelitian selanjutnya peneliti bisa menambahkan variabel kriminalitas yang lain sehingga sistem bias mencakup lebih banyak tindak kriminalitas di Kota Mataram.

\section{Daftar Pustaka}

[1] Sri Nurdiati, Baba Barus., Dwi Prasetyo., Pengembangan Sistem Informasi Geografis Tindak Kejahatan Multilevel berbasis Web (SIGITKEM), Seminar Nasional Informatika, Bogor.

[2] Sisilia, Aveati , 2015, Sistem Informasi Geografis Daerah Rawan Kriminalitas di Kota Pontianak Berbasis Web, Jurnal Teknik Informatika dan Sistem Informasi , Teknik Informatika Universitas Tanjungpura, Pontianak.

[3] Damayanti, I Nyoman Piarsa, I Made Sukarsa., 2016, Sistem Informasi Geografis Pemetaan Persebaran Kriminalitas di Kota Denpasar, Universitas Udayana, Denpasar.

[4] Khairul Imtihan. Perencanaan Strategi Sistem Informasi Pendidikan Pada Sekolah Tinggi Manajemen Informatika dan Komputer (STMIK) Lombok. Bianglala Informatika, 2015, 3.2.

[5] Lukman, M., Bagye, W., Fahmi, H., \& Imtihan, K. (2019). PEMANFAATAN TEKNOLOGI GOOGLE MAPS API UNTUK APLIKASI PENDETAKSIAN LOKASI RAWAN KRIMINALITAS BERBASIS ANDROID Studi kasus: Desa Ganti dan Desa Mujur, Kecamatan Praya Timur, Kabupaten Lombok Tengah. Jurnal Informatika dan Rekayasa Elektronik, 2(1), 52-59.

[6] Supriadi, D., Fahmi, H., \& Imtihan, K. (2018). ANALISA DAN PERANCANGAN INFRASTRUKTUR JARINGAN WIRELESS LOCAL AREA NETWORK (WLAN) PADA DINAS PERINDUSTRIAN DAN PERDAGANGAN KABUPATEN LOMBOK TENGAH. Jurnal Informatika dan Rekayasa Elektronik, 1(2), 1-6. 